\title{
THE JIDA CONFERENCE: TEACHING PRACTICE AS RESEARCH
}

\author{
Berta Bardí-Milà (iD, Daniel García-Escudero \\ Universitat Politècnica de Catalunya (Spain) \\ berta.bardi@upc.edu,daniel.garcia-escudero@upc.edu
}

Received February 2018

Accepted March 2018

\section{Abstract}

The Workshop on Educational Innovation in Architecture (JIDA) promotes reflection and debate among the faculty of the different schools of architecture. The communications presented in the five editions held so far (2013-2017) can be considered a "living archive" of the teaching practices of more than thirty Spanish and twenty foreign universities. This material is extremely helpful for improving the education of architects and to lay the foundations for research into the instructional scenario in this discipline. With this purpose in mind, work is being done on a constellation of terms related to pedagogical practices, which is intended to conceptualize the diversity of strategies and methodologies presented these years at the conference. This sample of teaching experiences is a base upon which to consider the current situation of schools of architecture and to ask ourselves: what will training be like for architects 20 years from now?

Keywords - JIDA, Workshop on Educational Innovation in Architecture, Teaching, Architecture, Research, Innovation.

\section{On the Need for Teaching Reflection}

The Workshop on Educational Innovation in Architecture (JIDA) posits the education of architects as a key topic for the discipline. In line with what is indicated by the International Union of Architects (UIA), the training of future professionals constitutes one of the greatest challenges for the constructed environment and its environmental, patrimonial and cultural balance. Universities and training centers have the responsibility to improve the theoretical and practical training of future architects in order to enable them to meet the expectations of the societies of the 21 st century. It is for this reason that the conference promotes reflection and debate among the faculty members and students of the most diverse institutions and schools.

A large part of these reflections revolve around the three spheres that define the activity of any school of architecture: the profession, teaching and research. These are usually associated in pairs with one another. The profession-teaching vector links classrooms to the real world of designing and building, one of the tasks that is still crucial for any architect. The profession-research vector is implemented in one of two ways: either setting up research groups as offices, or with university-business partnerships and the development of patents, products or construction solutions. The same thing does not occur with the teaching-research vector, which could be called: "teaching practice as a form of research". Although the research dimension of any university professor is increasingly promoted, we mustn't forget that their main mission is to educate. From this vector, which envisages instruction not only as an educational or pedagogical practice, but also as a field of research in and of itself, raises the possibility of not only improving the current courses, but also formulating new ones, organizing seminars to prepare future instructors or presenting research projects. 


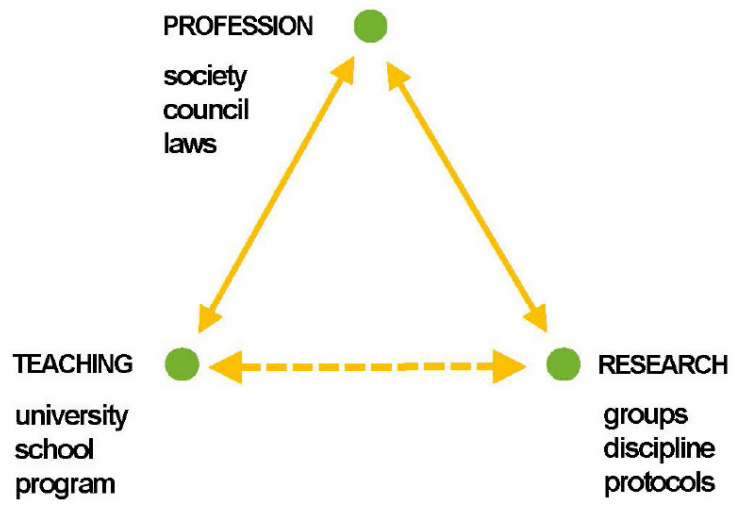

Figure 1. Areas of work and reflection in the schools of architecture

\section{The Context of Educational Research}

Besides publications traditionally dedicated to topics of educating architects, such as The Journal of Architectural Education, in recent decades initiatives have abounded that are aimed at reflecting on the state of education for architects, from both the professional and academic worlds. Framed within this context is an important article by Peter Buchanan: "What is wrong with architectural education: almost everything", published in The Architectural Review (Buchanan, 1989). Thirteen years later, the same author re-examines the discourse with the article "Rethinking Architectural Education" (Buchanan, 2012), in a special issue of the same journal dedicated exclusively to educational topics. This special issue not only includes research and critical reflections on the current training of architects, it also presents the Global Architecture Graduate Awards, promoted by the journal and intended to highlight the best student exercises from schools around the world. Other journals specialized in architecture, but not exclusively in teaching, such as Field and Volume, also hold regular open debates on the education of future architects and their relation to other fields of transforming the environment, culture and politics.

Likewise, in recent years, there have been several institutions and universities related to architect training that have published volumes gathering their academic and educational tradition. This is the case of the Yale School of Architecture (Hayes, 2007; Stern \& Stamp, 2016) and the Faculty of Architecture at the University of Porto (Faria, 2014). Other studies and research have gathered the history of what has been the formal training of architects since the end of the 18th century in North America and the United Kingdom: Architecture School: Three Centuries of Educating Architects in North America (Ockman, 2012) and Radical Pedagogies: Architectural Education and the British Tradition (Froud \& Harriss, 2015). In the closest context, the syllabi for the Rafael Moneo course in the Barcelona School of Architecture during the 1970s have just been published (Moneo, 2017), which explain to a large extent the later instructional and theoretical trends. With a much more global and modern profile is the publication Educating Architects: How tomorrow's practitioners will learn today (Spiller \& Clear, 2014), with contributions from important instructors and professionals from around the world and a more diverse theoretical and practical spectrum.

In terms of research projects, of particular interest is Radical Pedagogies, led by Beatriz Colomina (2012) from Princeton, in collaboration with more than twenty countries. On a European level, the Oikodomos project stands out, which was implemented through a network of European universities that offer courses on contemporary homes. The participating universities work in a collaborative way, offering workshops, seminars and regular student exchanges. On a Spanish level, some recently created schools, such as the EINA in Zaragoza, have promoted from the onset conferences and publications that gather and analyze their teaching practices. This saw the birth of the educational project: Metodologia docente del proyecto arquitectónico (Teaching methodology of the architectural project) (Labarta-Aizpún \& Bergera-Serrano, 2014). Older schools, such as the Madrid School (ETSAM-UPM), have also promoted educational innovation strategies, such as the Mentoring Program (Jalón-Oyarzun, Gelabert-Amengual, Lapayese-Luque \& Pieltáin-ÁlvarezArenas, 2014), for example, that enables graduate students to take part in teaching internships. On other 
occasions, the focus of these initiatives goes beyond architectural studies, to cover the entire university setting. This is the case of ERAGIN (Guisasola \& Garmendia, 2014), a teacher training program at the University of the Basque Country that seeks to promote the use of active methodologies in its different degree programs.

There are also more than a few conferences that bring together professionals from very different fields to share their experiences and reflections on education. In recent years, universities such as Yale and Princeton have held important conferences, such as Teaching Architecture, Practicing Pedagogy. In the European context, regular events such as The Antwerp Design Seminars \& Lectures stand out, like the one held in 2012 entitled: "Theory by Design" (De Vos, De Walsche, Michels \& Verbruggen, 2013). The different professional bodies and associations have also considered these topics. This was the case of the "La formación del arquitecto" (Architect training) symposium held at the Barcelona Architectural Association (COAC) headquarters in 2005. The RIBA also gave rise to the digital forum "Building Futures", a think-tank with annual meetings and digital publications that ponder the future of architects. In 2012, it launched the question: How will architects be educated in 20 years?

\section{The JIDA: a Living Archive}

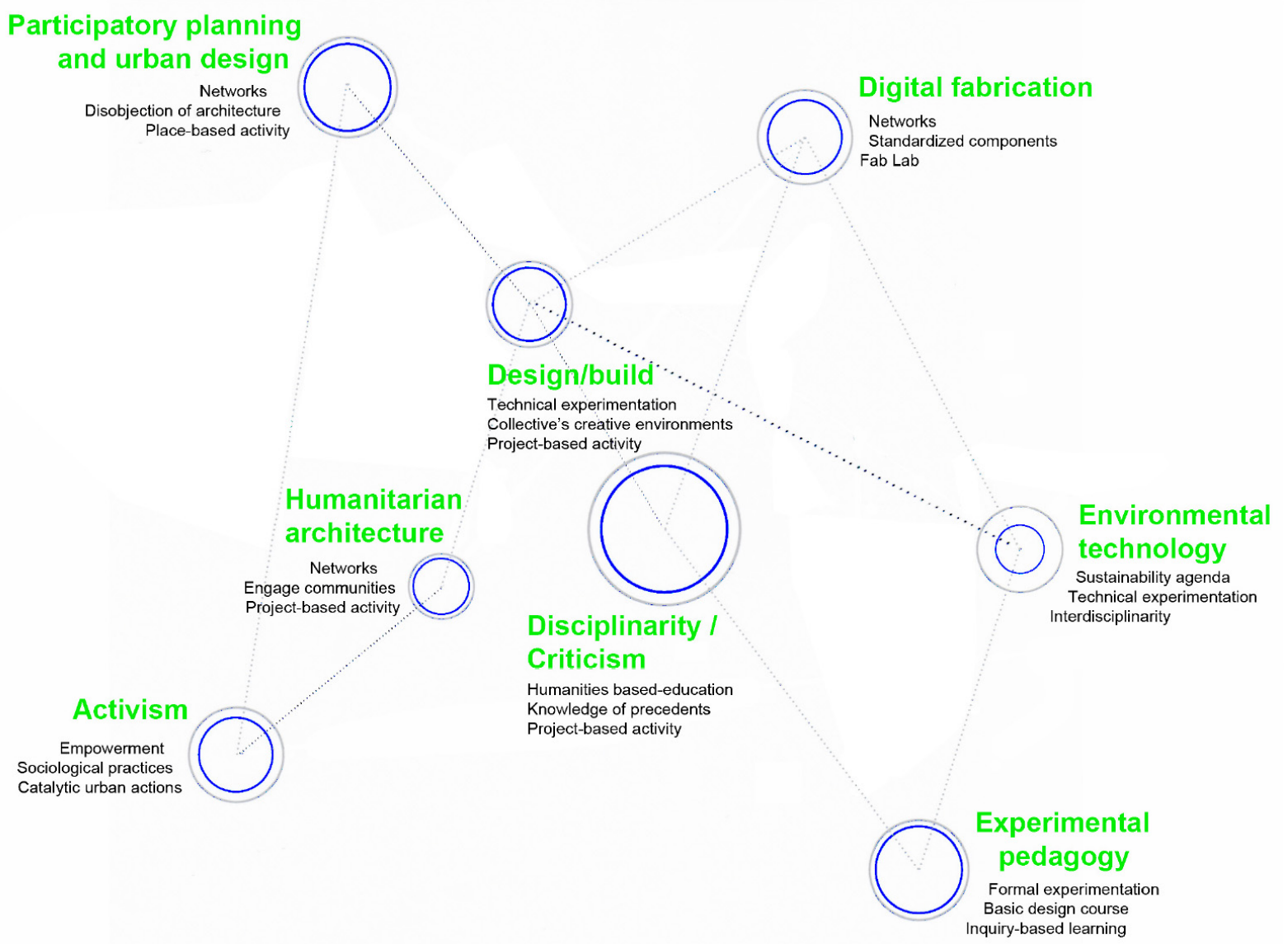

Figure 2. Constellation of teaching practices

In this context, the JIDA conference could be considered a true "living archive" of teaching practices from more than thirty Spanish and around twenty foreign universities to date (2013-2017). These teaching practices, collected in annual digital records (http://revistes.upc.edu/ojs/index.php/JIDA/issue/archive) have become material not only to help improve the education of architects, but also to build the bases for research upon which to draw general conclusions. This leads to reflections on the most appropriate ways to organize this material and classify it. With this purpose in mind, work is being done on a constellation of terms related to pedagogical practices, which is intended to conceptualize the diversity of strategies and methodologies found in the educational experiences presented over these years at the conference. The 
constellation includes eight recurring practices that attempt to define the entire training picture. The terms used are not new, rather they collect the most commonly used denominations in the specialized publications.

Likewise, an alternative way of organizing these practices is to concentrate on two current matters of maximum importance: networking versus individual work, and active methodologies versus passive ones. Consequently, classic teaching practices, such as discipline-critique, very common in design studios, are positioned on the opposite pole of methodologies, such as the design/built, based on collaborative work and an active approach to knowledge.

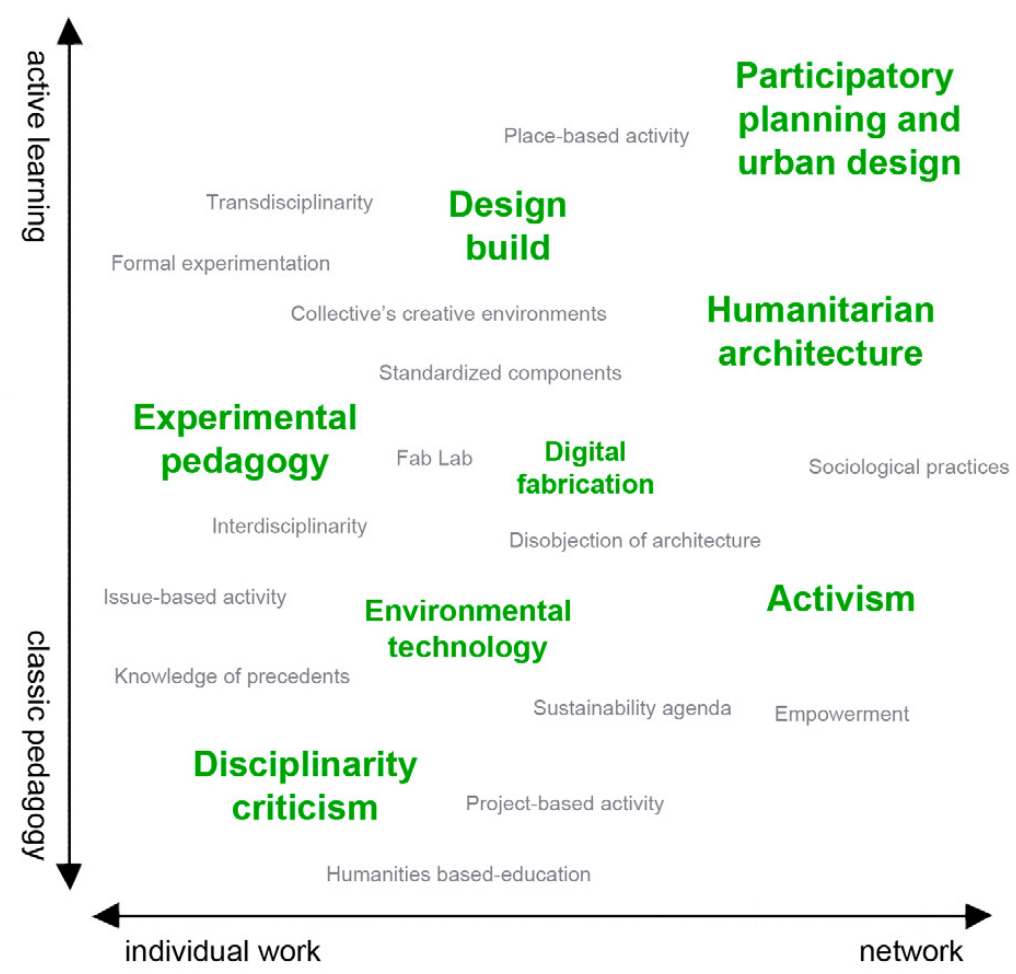

Figure 3. Diagram of teaching practices

Next, a summary review of this constellation is proposed, based on specific examples presented in the five editions of the JIDA conference.

First are the so-called experimental pedagogical approaches, which are very common in basic design courses, developed in mythical schools such as the Bauhaus school. These practices set the guidelines for formal abstraction, interdisciplinary and active practice. One contemporary example of this group is the "Curso experimental de introducción al proyecto del Laboratorio de Tizas" (Chalk laboratory experimental introduction to projects course), led by Antonio Juárez at the ETSAM-UPM and presented at JIDA'16 (Juárez-Chicote, 2016). This experience is based on the analysis of the work by Jorge Oteiza, from which it gets its name. In it, students work exclusively with $12 \times 12 \times 90 \mathrm{~mm}$ pieces of chalk which, constrained by material, instrumental and spatial restrictions in a grammar-like form, take on increasingly greater levels of complexity. Some of the guidelines followed in the laboratory are: contact with the material, the fluctuation between action and reflection, the demand for precise verbalization and representation and the creation of rough estimates and divergent alternatives for each solution. In essence, it is an initial training workshop in which the pre-formal or pre-project state are the condition being sought, considering this matter to be an essential requirement for architect training.

In turn, as has already been pointed out, the so-called discipline-critique could be considered the most common educational strategy in design studios, based on a disciplinary knowledge that is stimulated through specific programs and sites. An example of this group is "Proyectos I" (Projects I), from the 
second year at the EINA-UNIZAR school, led by Iñaki Bergera (Labarta \& Bergera, 2012). It is a projects course that focuses on the exemplary nature of the models in modern and contemporary architecture as a basis for completing three exercises. These propose the extension of emblematic pieces of architecture from the 20th century so that the students' first encounters with blank paper find in these references a support for expressing the first lines of their creativity as project designers. This support is more than a graphic or formal model, and it requires students to think about the broad topics that give shape to and articulate projects: scale, function, dimension, construction, language, etc. In short, the example serves as a point of support from which to begin to understand and work with the project logic.

One particular slant to the project workshops and the discipline-critique is the design/built, which leads them to overcome the simulation dimension of the exercises to actually end up building them, on many occasions in a collaborative manner. The initial traces of these practices can be found in schools such as the Bauhaus school in Dessau, but also in the Yale School of Architecture during the 1960s, under the guidance of Charles Moore, or more recently in the Rural Studio of the University of Auburn, or in workshops by Andrea Deplazes at the ETH in Zurich (Deplazes, Linares de la Torre \& Salmerón-Espinosa, 2017). One of the courses in "Introducción al proyecto" (Introduction to projects) at the ETSA-US, under the direction of Rodrigo Carbajal and Silvana Rodrigues, is based precisely on this tradition (Carbajal-Ballell \& Rodrigues-De-Oliveira, 2016). They intend to promote the immersion of first-year students in the reality of the architectural project, using the construction of living space as a vehicle for learning. After some preparatory exercises, students focus on the development of the project for an exhibition pavilion, first individually and then in groups. The pavilion ultimately built houses the models of the previous individual and group proposals. The model, built to a 1:1 scale, thus becomes the vehicle to communicate, test and apply the acquired knowledge. In it, students experiment with and clearly perceive theoretical concepts, such as a scale, composition and spatial sequence.

On the other hand, participative-urbanism is more and more present in the urbanistic workshops offered by the schools. These workshops are frequently linked to real users and their local managers, involving them as agents in the instruction both inside and outside the classroom walls. This is the case of "Proyectos Urbanos y Paisajísticos Integrados" (Integrated Urban and Landscaping Projects) of the qualifying Master's degree at the University of Zaragoza, coordinated by Javier Monclús (Monclús, Bambó-Naya, Cal \& García-Pérez, 2017). This course considers interventions for urban regeneration in vulnerable areas of the greater city area. The driving force of the workshop is working in a context with a strong social component, in which students can capture the different sensitivities and motivations of the social agents committed to a certain vulnerable neighborhood. To do this, work is done on a real project that is physically close, but in particular, in areas in which synergies can be found with the agents involved in urban governance, not only the administration, but also the social fabric represented in neighborhood associations.

Closely linked to the participative workshops of an urban nature are also activist practices arising from the counterculture movements of the 1960s, which make architectural practice a political activity and the deprogrammed action an instructional tool. Along these lines is the first-year course "Especulacciones" (Specul-actions) at the ETSAM-UPM, created by Atxu Amann (Amann, 2016). In this innovative workshop, the instructional practice is understood in itself as a political and architectural practice, rather than a simulation. It consists of a preparatory workshop with strategic actions linked to project design that uses a flexible and experimental instructional model. Through short strategic actions, the intent is to give students the capacity to be free, destroying the collective imagination, questioning the everyday foundations from risky estrangement procedures. While the term workshop refers to a productive learning model, in this course, students learn while doing something; but in this case, the objectives are not immediate and the capacities are not utilitarian. This workshop is interested in the self-learning that can be characterized without the need to introduce the notion of teaching.

In terms of humanitarian architecture, at the conferences held during these years, several initiatives have been presented from the "UNESCO chair in earthen architectures, constructive cultures and 
sustainable development", specifically their delegation at the ETSA-UPV (Mileto, Vegas, Cristini \& García-Soriano, 2015), (García-Soriano, Cristini, Blanco-Tamayo \& Tomás-Márquez, 2016). This chair proposes a high level of extra-university and humanitarian involvement in the educational action, using it as a stimulus for learning and a resource for the growth of the social conscience. These humanitarian practices are usually linked with the design/built methodology and specific action in certain disadvantaged and third-world enclaves. Specifically, the UNESCO courses consist of a varied range of instructional and outreach initiatives for adults and children. They are based on active learning methodologies aimed at tasks of analysis and joint reflection on earthen architecture, their historic validity and their contemporary potential.

On the opposite pole from these initiatives are the digital production workshops. One of the consequences that has been observed after more than two decades of use of advanced digital tools in architecture is a tendency to homogenize the nuances and diversity of the inputs from the participants in a creative process. It also has consequences for the final results, which tend to produce repetitive self-referencing solutions foreign to any context. The instructional innovation initiative "Politics of Fabrication Laboratory (PFL)," created by Francisco González de Canales and Núria ÁlvarezLombardero, arises a way of re-situating digital production processes in the contemporary political, social and constructive reality and placing them back into a collective dimension more closely linked to the real physical construction processes (González de Canales \& Álvarez-Lombardero, 2017). In the two experiences carried out in Chile and Havana, the starting premise has been to make digital production a collective, diverse and plural reality, and to combine it with a manual and collaborative development and installation.

Finally, numerous international organizations have stressed the urgency and importance of education for sustainability in all areas of education, especially at the university level (Mestre \& Roig, 2015). Its profound effects on the areas of knowledge related to applied creativity require a strong educational renewal, and one which current polytechnic academic structures find difficult to incorporate. As compared to the focus of classic teaching, this pedagogy requires us to take a peripheral view typical of a new centrifugal context. Thus, disciplines such as the environmental sciences and ecology should form a more active part of the curricular contents. The European EDUCATE project has been subsidized by the Intelligent Energy Europe Program and the European Competitiveness Agency as the result of its interest in fostering the permanent incorporation of the environmental design in the university curricula of schools of architecture, as well as in ongoing professional training.

\section{Some Partial Conclusions and Challenges for the Future}

This small sample of educational experiences, along with the dozens archived in the JIDA, are a base upon which to consider not only the current situation of architect training, but also its near future. It is worth asking, then: What will training be like for architects 20 years from now? It was precisely in 2012, at the RIBA's Building Futures forum, where a small group of experts were asked this very question as part of a debate on the future of architects. One of these experts, Jeremy Till, argued that the duration and location of the courses will be quite varied. Education will no longer be determined by the time, but rather the quality of the experience. It will be based, at least in part, on the exercise of the profession, accredited through a critical reflection on the students' practice. In this way, students will enter and leave formal education, accelerating parts of their courses and taking more time with others. Static knowledge will be replaced by a flexible, collective intelligence (Till, 2005).

Jeremy Till indicates a series of key questions, such as the relationship between the profession and academia, and between theory and practice, and making studies more flexible, in terms of both time and space. There are currently professional internships set up to complement formal studies and exchanges between architecture schools, which give students the possibility to experiment other academic and cultural environments. However, these experiences normally occur without any strong coordination with the core courses in the schools of origin. These academic and especially professional exchanges, are one of the keys to opening up the university to society. This is why the nascent postgraduate school the 
London School of Architecture has emerged, created and directed by Will Hunter. With the desire to link academia and practice, the school has emerged as a flexible working network intended to link the university with the profession, architecture to other disciplines and the school with the city. Hence, it has been organized on a biannual basis, including during the first year, three days of practical training in studios, coordinated with the school and two days of formal instruction. A second full-time year was offered at the school, dedicated to projects in relation to London and the surrounding area.

This type of post-graduate experiences, similar to others offered at American universities, lead us to envision an architectural education that must progress from the autonomy of the discipline to its most heteronomous aspects. In the early courses, students are still ill-equipped, unaware of the tools and basic techniques of architecture. At this moment it is thus necessary to equip them, to give them essential knowledge. In other words, it is recommended to talk about the autonomous aspects of architecture, about its internal laws, its forms and rules, as they are necessary, even if they are not currently in fashion. That objective condition will be implemented with aspects more closely related to today's contemporary reality. As the courses progress, the students are increasingly more autonomous and acquire their own judgment that enables them to introduce aspects that surround architecture and condition it, i.e., heteronomous and interdisciplinary aspects: the program, society, culture, technology, etc.
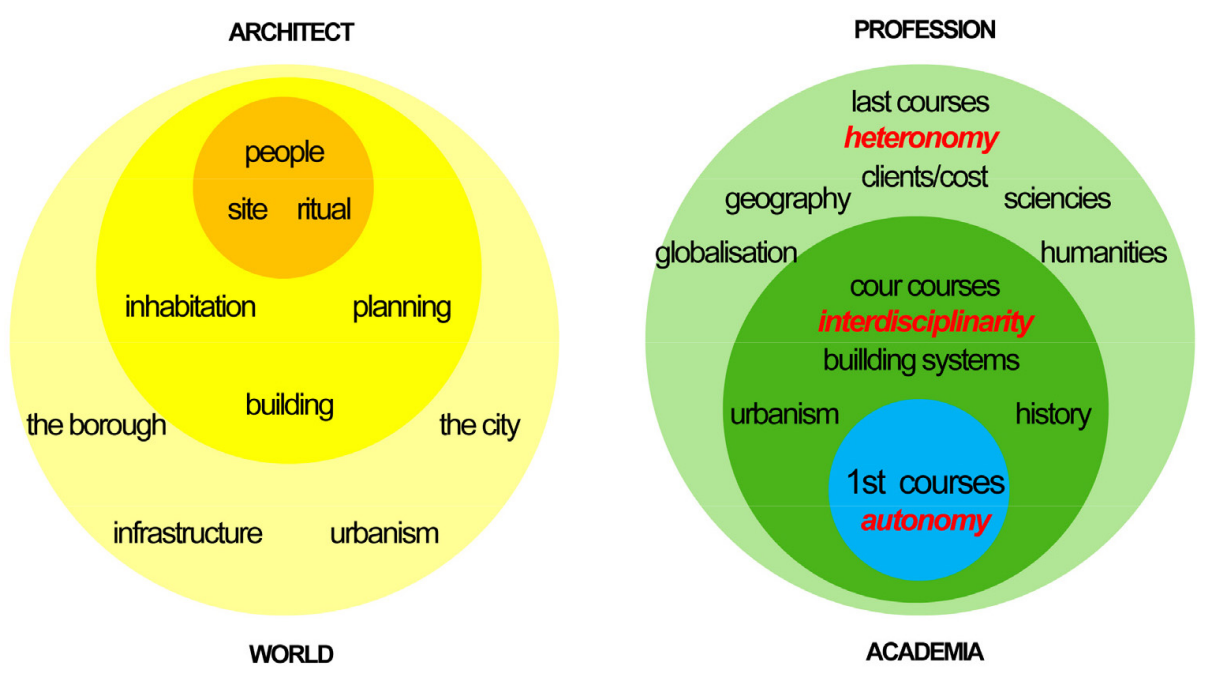

Figure 4. Spheres related to the teaching of architecture

Ultimately, the schools of architecture must be a university environment with their drawbacks and contradictions, but open to reflection, to the confrontation of ideas and contact between all those who aspire to broaden their perspective and expand their knowledge in this discipline. The schools must assume, now more than ever, the role of nuclei of cultural change, as no other institution can take their place with regard to this task. The school cannot remain on the sidelines of what happens in the professional arena. But instead of accepting a subsidiary status and being limited to being an instrument of the professional framework, it must be a crossroads, an area for debate.

\section{Declaration of Conflicting Interests}

The authors declared no potential conflicts of interest with respect to the research, authorship, and/or publication of this article.

\section{Funding}

The authors received no financial support for the research, authorship, and/or publication of this article. 


\section{References}

Amann y Alcocer, A. (2016). Innovación en el aprendizaje arquitectónico de lo inútil, especulacciones: taller de acciones ligadas al proyectar. In JIDA'16, Jornadas sobre Innovación Docente en Arquitectura, 20-21 October, Valencia. http://hdl.handle.net/2117/97743

Buchanan, P. (1989). What's wrong with architectural education? Almost everything. Architectural Review, 19(5).

Buchanan, P. (2012). The Big Rethink: Architectural Education. Architectural Review, 232(1388).

Building futures. (2012). The future of architectural education. RIBA.

http://www.buildingfutures.org.uk/think/theme/2/2

Carbajal-Ballell, R., \& Rodrigues-De-Oliveira, S. (2016). Inmersión en el proyecto arquitectónico: ideación, debate y construcción. In JIDA'16, Jornadas sobre Innovación Docente en Arquitectura, 20-21 October, Valencia. http://hdl.handle.net/2117/97959

Colomina, B. (2001). Radical pedagogies. Princeton University, School of Architecture. http://radicalpedagogies.com/

De Vos, E., De Walsche, J., Michels, M., \& Verbruggen, S. (2013). Theory by design: architectural research made explicit in the design studio. Brussels: UPA University Press Antwerp.

Deplazes, A., Linares de la Torre, O., \& Salmerón-Espinosa, M. (2017). Learning by building: Dos experiencias didácticas de la Cátedra Deplazes ETH-Z. In JIDA'17, Jornadas sobre Innovación Docente en Arquitectura, 16-17 November, Sevilla. http://hdl.handle.net/2117/109588

Faria, N. (2014). Porto School: B side/An oral history (1968-1978). Guimaraes: A Oficina, CIPRL Sistema Solar.

Froud, D., \& Harriss, H. (2015). Radical Pedagogies: Architectural Education and the British Tradition. Newcastle upon Tyne: RIBA Publishing.

García-Soriano, L., Cristini, V., Blanco-Tamayo, E., \& Tomás-Márquez, S. (2016). La arquitectura de tierra en la infancia para la sensibilización al desarrollo sostenible. In JIDA'16, Jornadas sobre Innovación Docente en Arquitectura, 20-21 October, Valencia. http://hdl.handle.net/2117/98058

González de Canales, F., \& Álvarez-Lombardero, N. (2017). Colaboración, cooperación, disensión. Modos de abordar el trabajo en grupo en la era de la fabricación digital. In JIDA'17, Jornadas sobre Innovación Docente en Arquitectura, 16-17 November, Sevilla. http://hdl.handle.net/2117/109591

Guisasola, J., \& Garmendia, M. (2014). Aprendizaje basado en problemas, proyectos y casos: diseño e implementación de experiencias en la universidad. Servicio Editorial de la Universidad del País Vasco. https://www.ehu.eus/documents/1870360/2202435/Eragin+Liburua+\%282\%29.pdf

Hayes, R.W. (2007). The Yale Building Project: The First 40 Years. New Haven: Yale University Press.

Jalón-Oyarzun, L., Gelabert-Amengual, A., Lapayese-Luque, C., \& Pieltáin-Álvarez-Arenas, A. (2014). Estrategias de innovación y formación en la docencia: un proyecto de innovación educativa UPM. In XI Jornadas Internacionales de Innovación Universitaria, Educar para transformar, 7-8 julio 2014, Madrid. http://hdl.handle.net/11268/3645

JIDA, Jornadas sobre Innovación Docente en Arquitectura. http://revistes.upc.edu/ojs/index.php/JIDA/issue/archive

Juárez-Chicote, A. (2016). Dimensión mínima, apertura máxima: hacia un alfabeto del proyecto arquitectónico. In JIDA'16, Jornadas sobre Innovación Docente en Arquitectura, 20-21 October, Valencia. http://hdl.handle.net/2117/98249 
Labarta-Aizpún, C., \& Bergera-Serrano, J.I. (2012). Memoria de Proyectos 2010.11. Zaragoza: Prensas Universitarias de Zaragoza, Universidad de Zaragoza.

Labarta-Aizpún, C., \& Bergera-Serrano, J.I. (2014). Metodología e innovación docente del Proyecto Arquitectónico: la experiencia del Departamento de Arquitectura de la Universidad de Zaragoza. In JIDA'14, Jornadas sobre Innovación Docente en Arquitectura, 28-29 April, Barcelona.

http://hdl.handle.net/2099/14616

London School of Architecture. http://www.the-lsa.org/

Mestre, N., \& Roig, E. (2015). Sostenibilidad y otras demandas contraintuitivas de la pedagogía de la creatividad. In JIDA'15, Jornadas sobre Innovación Docente en Arquitectura, 25-29 May, Barcelona. http://hdl.handle.net/2117/81693

Mileto, C., Vegas, F., Cristini, V., \& García-Soriano, L. (2015). Enseñanza orientada a la acción: propuestas de la Cátedra UNESCO de Arquitectura de Tierra, Culturas Constructivas y Desarrollo Sostenible UNITWIN/UPV. In JIDA'15, Jornadas sobre Innovación Docente en Arquitectura, 25-29 May, Barcelona. http:/ hdl.handle.net/2117/81537

Monclús, J., Bambó-Naya, R., Cal, P. de la, \& García-Pérez, S. (2017). Cuatro años de talleres de regeneración urbana: el aula proyectada en la ciudad. In: JIDA'17, Jornadas sobre Innovación Docente en Arquitectura, 16-17 November, Sevilla. http://hdl.handle.net/2117/109599

Moneo, R. (2017). Rafael Moneo: una manera de enseñar arquitectura. Barcelona: Iniciativa Digital Politècnica, Oficina de Publicacions Acadèmiques Digitals de la UPC.

Ockman, J. (2012). Architecture School: Three Centuries of Educating Architects in North America. Cambridge, Mass.: MIT Press; Washington, D.C.: Association of Collegiate Schools of Architecture.

Oikodomos. http://www.oikodomos.org/

Spiller, N., \& Clear, N. (2014). Educating Architects: How tomorrow's practitioners will learn today. London: Thames \& Hudson.

Stern, R.A.M., \& Stamp, J. (2016). Pedagogy and Place: 100 years of Architecture Education at Yale. New Haven: Yale University Press.

Till, J. (2005). Lost Judgement. In: Harder, E. EAAE Prize 2003-2005 Writings in architectural education. Copenhagen: European Association for Architectural Education, 164-184.

Published by OmniaScience (www.omniascience.com)

Journal of Technology and Science Education, 2018 (www.jotse.org)

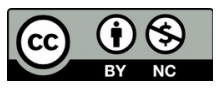

Article's contents are provided on an Attribution-Non Commercial 4.0 Creative commons International License. Readers are allowed to copy, distribute and communicate article's contents, provided the author's and JOTSE journal's names are included. It must not be used for commercial purposes. To see the complete licence contents, please visit https://creativecommons.org/licenses/by-nc/4.0/. 